\title{
Abstract
}

\section{An Integrated Water Curtain-Microalgal Culture System (WCMC) to Mitigate Air Emissions and Recover Nutrients from Animal Feeding Operations}

\author{
Qianfeng Li ${ }^{1,2 *}$, Wendy Powers ${ }^{1,3}$, Dale Rozeboom ${ }^{3}$, Yan Liu ${ }^{1}$, and Wei Liao ${ }^{1}$
}

${ }^{1}$ Department of Biosystems and Agricultural Engineering, Michigan State University, East Lansing, MI 48824, USA

${ }^{2}$ Center For Global Change \& Earth Observations, Department of Geography, Michigan State University, East Lansing, MI 48824, USA

${ }^{3}$ Department of Animal Science, Michigan State University, East Lansing, MI 48824, USA

*Please address correspondence to: Qianfeng Li, email: qianfengli@ gmail.com, phone: +1517-353-2290, fax: +1-517-353-1699.

Economically and technologically feasible air emission mitigation technologies are in high demand to sustain future animal agriculture. In this study, we designed an integrated Water Curtain-Microalgal Culture (WCMC) system to mitigate air emissions and recover nutrients to culture microalgae from Animal Feeding Operations (AFOs). The WCMC system included a water curtain, a windbreak wall and a raceway pond bioreactor. The water curtain was formed by continuously pumping water into a perforated water tank that flowed into the raceway pond bioreactor. The exhaust pollutants $\left(\mathrm{NH}_{3}\right.$ and particulate matter-PM) from a poultry house were dissolved and absorbed by the water droplets. Microalgal species were collected from local ponds and went through natural selection. Desmodesmus (R. Chodata) showed the best tolerances of temperature, nutrients, $\mathrm{pH}$, and circulation shear force. The microalgal culture in the bioreactor was run in batch mode and the average productivity was $12.7 \pm 2.9 \mathrm{~g} / \mathrm{m}^{2} / \mathrm{day}$. Exhaust ammonia $\left(\mathrm{NH}_{3}\right)$ and total suspended particle (TSP) concentrations were reduced by $74.9 \%$ and $89.2 \%$, respectively. The harvested microalgal biomass had a protein content of 41.3\%. The amino acid profile of microalgae demonstrated comparable quality to the WHO/FAO reference. Omega-3 fatty acids accounted for about $23 \%$ of total fat acids. Heavy metals $(\mathrm{Pb}, \mathrm{Cu}$, 
28 Fe and $\mathrm{Zn}$ ) did not exceed the tolerance levels. The adaptation of this new technology will

29 reduce AFOs environmental impact, create a win-win situation for future animal agriculture and

30 microalgal cultivation, and generate new alternative protein sources as food and feed

31 supplements.

32 Keywords. Air emission mitigation, microalgal culture, water curtain, nutrient capture and

33 reuse, wet spay scrubbers

\section{Introduction}

35 Animal feeding operations (AFOs) bring opportunities and economic growth to rural

36 communities [1], though, extension of AFOs leads to some potential environmental issues,

37 including odor and air pollutions. Major air emissions from $\mathrm{AFOs}$ include $\mathrm{NH}_{3}, \mathrm{CO}_{2}$, and

38 particulate matter (PM). Approximately, $50 \%$ of the total anthropogenic $\mathrm{NH}_{3}$ emissions in the

39 U.S. are from animal agriculture [1]. Exhaust $\mathrm{NH}_{3}$ and PM from AFOs contains major (N, P, S,

40 and $\mathrm{K})$ and minor ( $\mathrm{Fe}, \mathrm{Zn}, \mathrm{Cu}$, and $\mathrm{Na}$ ) nutrients [2, 3]. Dry and wet deposition of these airborne

41 nutrients could cause ecosystem eutrophication and acidification [1]. Mitigating air emissions is

42 essential to sustain animal agricultural operations, particularly AFOs. Wet spray scrubbers are

43 one of the most efficient approaches to mitigate air emissions [4-6]. Wet spray scrubbers utilize

44 liquid droplets to capture gases and particulate matter (PM) and have minimum resistance to air

45 flow. In spite of good mitigation efficiency of wet spray scrubbers, the effluent from the

46 scrubbers is rich in nutrients, and disposal of the effluent limits their application in AFOs. Fu, et

47 al. [7] demonstrated using reverse osmosis membrane to concentrate ammoniacal nitrogen from

48 wet scrubber effluent and recycling permeate as feed water in the acid scrubber system.

49 Hadlocon and Zhao [8] investigated the production of ammonium sulfate fertilizer from acid

50 spray wet scrubbers effluents. Besides these physical and chemical approaches of nutrient 
51 recovery, the effluent can also be used as nutrient-rich water to culture microalgae for value-

52 added animal feed production, which would improve the economic feasibility of wet spay

53 scrubbers in AFOs [9].

54 Microalgae have attracted considerable attention as potential feedstock for biofuel and

55 animal feed production $[10,11]$. Due to excellent nutrient compounds and digestibility of

56 microalgae, about $30 \%$ of the current world microalgae production is used in animal feed

57 application $[11,12]$. A swine feed trial found that docosahexaenoic acid (DHA)-rich microalgae

58 resulted in higher weight gain and feed conversion efficiency than control diet [13]. Evans, et al.

59 [14] incorporated $16 \%$ microalgae into broiler starter diets and did not find any performance

60 detriment. Ekmay, et al. [15] found weanling pigs and broiler chicks performed well with

61 dietary inclusion of $10 \%$ and $15 \%$ defatted green microalgal biomass, respectively. Utilization of

62 microalgae in aquaculture is another growing market, and they can be used directly in

63 aquaculture feeds [11]. These nutritional and toxicological studies demonstrated that microalgal

64 biomass could be used as a valuable feed supplement and substitute for convention protein

65 sources. However, large-scale microalgae production is still not cost-competitive because of high

66 demand on nutrients, water and energy [16-18]. Therefore, it is important to capture and recycle

67 nutrients from different sources to sustain microalgal cultivation for biofuels and animal feed

68 production. Reusing nutrients from agricultural waste streams could be an effective approach to

69 address the nutrient issue of microalgal cultivation. In addition, nutrient recovery also provides a

70 holistic solution to animal waste management [19-22].

71 Our previous study showed that microalgal cultivation was a promising technology to

72 mitigate $\mathrm{NH}_{3}$ and $\mathrm{PM}$ emissions from AFOs and the nutrients in the poultry house dust

73 significantly enhanced the microalgal growth [9]. The objective of this study was to develop an 
74 integrated Water Curtain-Microalgal Culture (WCMC) system for poultry operations that

75 mitigates air emissions, captures and reuses nutrients to produce microalgal biomass as potential

76 animal feedstock.

77 Materials and methods

78 Water Curtain-Microalgal Culture system (WCMC)

79 The WCMC system included a water curtain, a windbreak wall, a raceway pond bioreactor,

80 and an exhaust air blower system (Figure 1). The water curtain was formed by continuously

81 pumping water into a perforated water tank that flowed into the open pond bioreactor. Exhaust

82 pollutants (such as $\mathrm{NH}_{3}$ and $\mathrm{PM}$ ) were dissolved and absorbed into water curtain droplets. The

83 nutrient-rich effluent was used to culture microalgae. Two main products of the WCMC system

84 are clean air and protein-rich microalgal biomass.

\section{Water cutain and windbreak wall}

86 The dimensions of the perforated water tank were $0.625 \mathrm{~m} \times 0.476 \mathrm{~m} \times 0.352 \mathrm{~m}(\mathrm{~L} \times \mathrm{W} \times$

$87 \mathrm{H})$ with 30 holes $(10 \times 3$ rows, diameter $=7.94 \mathrm{~mm})($ Figure 2$)$. The water curtain flow rate was

$8816.0 \mathrm{~L} / \mathrm{min}$. The windbreak wall was $0.476 \mathrm{~m} \times 0.400 \mathrm{~m}(\mathrm{~L} \mathrm{x} \mathrm{H})$, and it was designed to reduce

89 air flow through the water curtain to increase the exhaust air retention time. The exhaust air from

90 a poultry house was delivered to the water curtain through a $10 \mathrm{~m}$ length and $0.102 \mathrm{~m}$ diameter

91 PVC pipe with an air flow rate of $0.05 \mathrm{~m}^{3} / \mathrm{sec}$. 

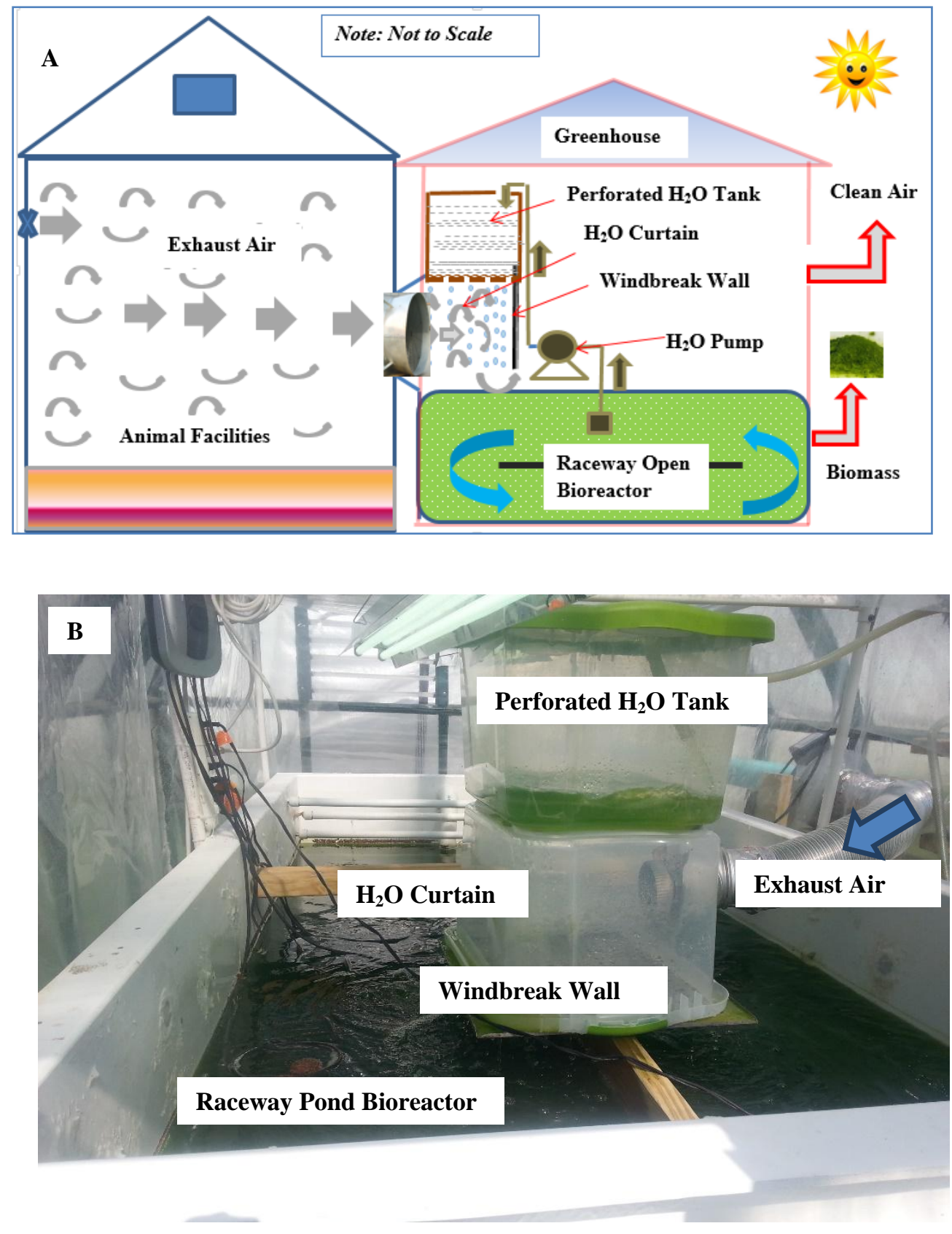

Figure 1. The integrated Water Curtain-Microalgal Culture system (WCMC)

\section{Raceway pond bioreactor for microalgal culture}

The raceway pond bioreactor for suspended microalgal culture was made of fiberglass with 
97 a dimension of $2.44 \mathrm{~m} \times 1.22 \mathrm{~m} \times 0.41 \mathrm{~m}(\mathrm{~L} \times \mathrm{W} \times \mathrm{H})$ and the working volume of $0.91 \mathrm{~m}^{3}$. The

98 raceway pond was driven by 4 aquarium pumps (Pentair Aquatics, Chino, CA) with a channel

99 velocity of $0.25 \mathrm{~m} / \mathrm{s}$. The reactor was placed in a greenhouse $(2.05 \mathrm{~m} \times 3.66 \mathrm{~m} \times 2.0 \mathrm{~m}(\mathrm{~W} \times \mathrm{L} \times$

$100 \mathrm{H})$ ) with 4 vents.

101

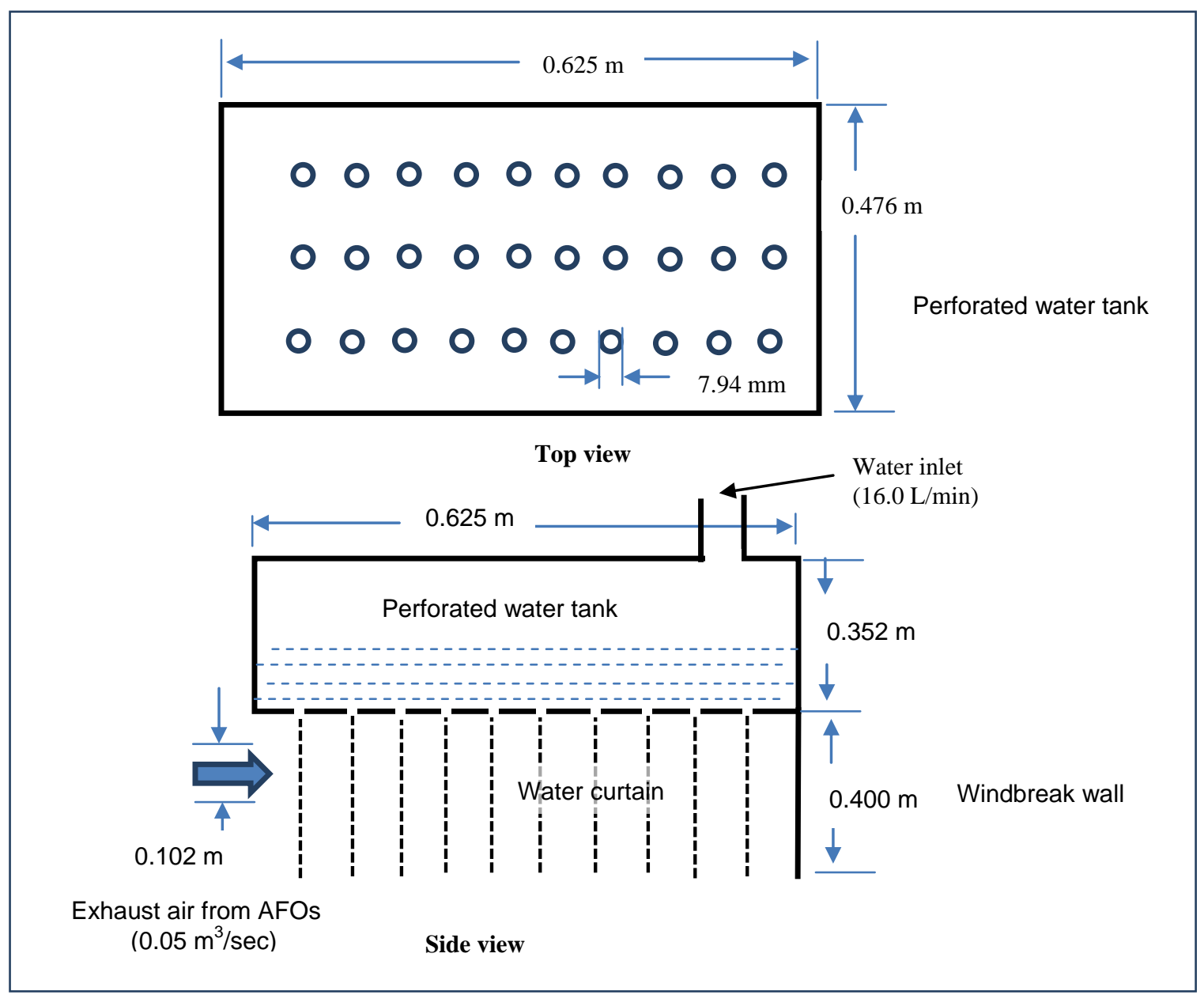

Figure 2. Section view of the water curtain and windbreak wall

103 Microalgae cultivation

104 Strain selection and morphological identification

105 The selection of microalgal strains that could grow in real environmental conditions is a

106 critical step in developing a reliable microalgal culture for utilizing the captured nutrients. The

107 selected strains must also be robust enough to outcompete potential contaminated microbes of 
108 bacteria, protozoa, and fungi. The parameters of temperature and nutrient were used to select the

109 best adapted microalgae that predominate the culture. Water samples containing native

110 microalgal species were collected from local ponds (Okemos, Michigan, U.S. Longitude: -

111 84.5789, Latitude: 42.7803) in September 2012. The selection and screening of targeted

112 microalgal strains included two steps: the collected water samples were first cultured on a shaker

113 at $200 \mathrm{rpm}$ for $3 \mathrm{~d}$ in the laboratory; the cultures were then moved to an outside greenhouse

114 (temperature ranged from $2{ }^{\circ} \mathrm{C}$ to $20{ }^{\circ} \mathrm{C}$ ) for 5 months. Wet scrubber effluent was used as a

115 nutrient source. Microalgal species went through natural selection and the surviving species were

116 used as the inoculum for the following microalgae cultivation.

117 Strain identification was based on morphologic properties of individual microalgae.

118 Microalgal cells were photographed at 100x magnification using a Nikon Eclipse 50i microscope

119 with the DS Camera Head DD-Fi1 (Nikon Instruments Inc., Melville, NY). The Nikon NIS

120 Elements imaging software was used to process the images. The distribution of microalgal

121 species was recorded based on cell counting.

\section{Microalgae culture and harvesting}

123 The microalgal inoculum was inoculated into the raceway pond bioreactor to carry out

124 nutrient removal and microalgal biomass accumulation. The cultivation temperature ranged from

$1255^{\circ} \mathrm{C}$ to $30^{\circ} \mathrm{C}$, and fluorescent lamps provided light intensity of 100 microeinstein $(\mu \mathrm{E}) / \mathrm{m}^{2} / \mathrm{sec}$

126 from $0600 \mathrm{~h}$ to $2100 \mathrm{~h}$. The microalgal culture in the bioreactor was run in batch mode and water

127 was recycled after harvesting the microalgal biomass. There were total four batches of

128 experiments from May, 2014 to August, 2014. Batch 1 (28 d) was the culture stabilizing period

129 and microalgae were adapting to the new environment. Batches 2-4 were three replicates running

130 for $15 \mathrm{~d}$ to $20 \mathrm{~d}$. Microalgal biomass was harvested after each batch by pumping out $90 \%$ of the 
131 microalgal suspension medium. The remaining $10 \%$ of medium was served as inoculum for next

132 batch cultivation. The microalgal suspension medium withdrawn from the reactor was naturally

133 gravity settled for $3 \mathrm{~d}$, then the top supernatant was collected and recycled back to the water

134 curtain operations. The settled microalgal biomass was centrifuged at $988 \mathrm{~g}$ for 5 min to collect

135 cell pellets and the pellets were freeze-dried for further analyses.

\section{Microalgal density and growth performance}

137 Microalgal suspension medium $(25.0 \mathrm{ml})$ were collected and stored at $4{ }^{\circ} \mathrm{C}$ prior to

138 microalgal density analyses during each day of the study. Total 149 samples were collected in 73

139 days of the cultivation. The microalgal biomass concentrations were monitored by measuring

140 optical density (OD) at $750 \mathrm{~nm}\left(\mathrm{OD}_{750}\right)$ (UV-2600/2700, Shimadzu Corporation, Japan) and then

141 converted to mass concentrations (g/L) using a calibration curve (Figure 3). Microalgal specific

142 growth rate was calculated by plotting the natural log of cell concentration over time.

143

$$
\operatorname{Ln}(x)=\mu^{*} t+\operatorname{Ln}\left(x_{0}\right)
$$

$144 \quad t_{d}=\frac{\operatorname{Ln}(2)}{\mu}$

145 Where $\mathrm{x}$ is the cell concentration, $\mathrm{t}$ is the time $(\mathrm{d}), \mathrm{x}_{0}$ is the initial cell concentration, $\mu$ is the 146 specific growth rate, and $t_{d}$ is the doubling time (d) in the exponential phase. 


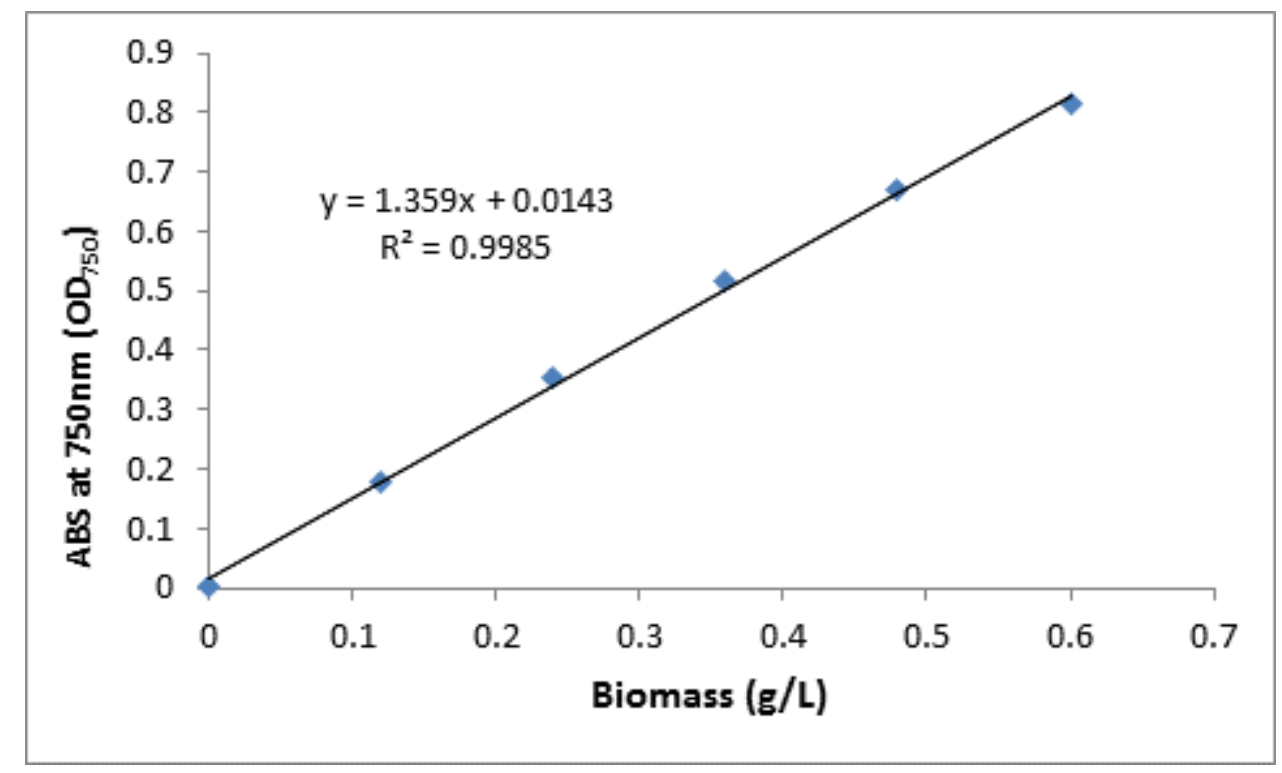

147

$$
\eta_{\mathrm{NH}_{3}}=\frac{\text { Conc }_{\mathrm{ExhNH}_{3}}-\text { Conc }_{\mathrm{CleanNH}_{3}}}{\mathrm{Conc}_{\mathrm{ExhNH}_{3}}} \times 100 \%
$$

155 Where

$156 \quad \eta_{\mathrm{NH}_{3}}=\mathrm{NH}_{3}$ mitigation efficiency $(\%)$

157 Conc $_{\mathrm{ExhNH}_{3}}=\mathrm{NH}_{3}$ concentration in the exhaust air from the poultry house before the WCMC $158(\mathrm{ppm})$

159 Conc $_{\text {CleanNH }_{3}}=\mathrm{NH}_{3}$ concentration in the cleaned air after the WCMC (ppm) 

using an INNOVA 1412 photoacoustic analyzer (5.1 ppm detection limit at 1,000 ppm range,

162 Lumasense Technologies, Ballerup, Denmark). The $\mathrm{CO}_{2}$ mitigation efficiency was defined as:

$$
\eta_{\mathrm{CO}_{2}}=\frac{\text { Conc }_{\mathrm{ExhCO}_{2}}-\text { Conc }_{\mathrm{CleanCO}_{2}}}{\mathrm{Conc}_{\mathrm{ExhCO}_{2}}} \times 100 \%
$$

164 Where

$165 \quad \eta_{\mathrm{CO}_{2}}=\mathrm{CO}_{2}$ mitigation efficiency $(\%)$

$166 \mathrm{Conc}_{\mathrm{ExhCO}_{2}}=\mathrm{CO}_{2}$ concentration in the exhaust air from the poultry house before the WCMC $167(\mathrm{ppm})$

168 Conc $_{\mathrm{CleanCO}_{2}}=\mathrm{CO}_{2}$ concentration in the cleaned air after the WCMC (ppm)

169 A filter-based method was used to determine total suspended particulate matter (PM $\left.\mathrm{PSP}_{\mathrm{TS}}\right)$ 170 concentrations. Filter samples were collected at the WCMC inlet (exhaust air) of the poultry 171 house and the WCMC outlet (cleaned air) of the greenhouse. Three samples were collected at the 172 beginning, middle and end of each batch. The sampling system consisted of a pump, a flow 173 meter, and a filter holder with a $46.2 \mathrm{~mm}$ diameter $2-\mu \mathrm{m}$ PTFE filter. The flow rate was 1.0

$174 \mathrm{~m}^{3} / \mathrm{hr}$ and the sampling duration was $24 \mathrm{hr}$. The air volume for sampling was calculated based on 175 time and air flow rate. The sampling filters were kept in plastic petri dishes during transportation 176 and storage. The $\mathrm{PM}_{\mathrm{TSP}}$ concentrations $\left(\mathrm{mg} / \mathrm{m}^{3}\right)$ were calculated using the sampling air volume $177 \quad\left(\mathrm{~m}^{3}\right)$ to divide the collected TSP weight $(\mathrm{mg})$.

178 The $\mathrm{PM}_{\mathrm{TSP}}$ mitigation efficiency was calculated:

$$
\eta_{T S P}=\frac{\text { Con }_{\text {ExhTSP }}-\text { Con }_{\text {CleanTSP }}}{\operatorname{Con}_{\text {ExhTSP }}} \times 100 \%
$$


$182 \operatorname{Con}_{E x h T S P}=$ Exhaust air TSP concentrations from the poultry house before the WCMC $\left(\mathrm{mg} / \mathrm{m}^{3}\right)$

183 Con $_{\text {CleanTSP }}=$ Cleaned air TSP concentrations after the WCMC $\left(\mathrm{mg} / \mathrm{m}^{3}\right)$.

\section{Nutrient $\left(\mathrm{NH}_{4}{ }^{+}-\mathrm{N}\right.$ and $\left.\mathrm{NO}_{3}{ }^{-}-\mathrm{N}\right)$ analyses}

185 The concentration of ammonium $\left(\mathrm{NH}_{4}{ }^{+}-\mathrm{N}\right)$ ions in aqueous medium was measured using 186 ammonium ion-selective electrode $\left(\mathrm{NH}_{4}\right.$-BTA, Vernier Software \& Technology, Beaverton, 187 OR). It was calibrated from 1 to $100 \mathrm{mg} / \mathrm{L}$ with the precision of $\pm 10 \%$ of full scale using $\mathrm{NH}_{3} \mathrm{Cl}$ 188 standard solution. The concentration of nitrate $\left(\mathrm{NO}_{3}{ }^{-} \mathrm{N}\right)$ ions in aqueous medium was measured 189 using nitrate ion-selective electrode $\left(\mathrm{NO}_{3}\right.$-BRA, Vernier Software \& Technology, Beaverton, 190 OR). It was calibrated from 1 to $100 \mathrm{mg} / \mathrm{L}$ with the precision of $\pm 10 \%$ of full scale using $\mathrm{NaNO}_{3}$ 191 standard solutions.

\section{Microalgal biomass composition analyses}

193 Freeze-dried biomass was used for chemical analyses, which was conducted by the

194 University of Missouri Agriculture Experiment Station Laboratory. The Kjeldahl method was 195 used to determine nitrogen content in microalgae (TKN; AOAC Method 928.08, 2000).

196 Microalgal amino acids profile was analyzed by an AOAC method (AOAC Method 982.30, 197 2006). A capillary gas-liquid chromatography was used to analyze fatty acids (AOAC official 198 method 996.06). Microalgal energy and element content were analyzed using bomb calorimetry 199 and microwave digestion followed by Inductively Coupled Plasma Mass Spectrometry (ICP200 MS). 
The PROC NLIN of SAS v. 9.4 (SAS Inst. Inc., Cary, NC) was used to simulate a

203 microalgal growth curve. The PROC TTEST was used to conduct pair-wise comparison for $\mathrm{NH}_{3}$,

$204 \mathrm{CO}_{2}$, and TSP mitigations.

\section{Results and Discussion}

\section{Selection of microalgal strains}

207 The original microalgal assemblage mainly consisted of $95 \%$ of Rhizocloniu spp and 208 Pediastrum (Figure 4). Rhizocloniu spp is a filamentous microalgae with a cell diameter of 20 -

$20930 \mu \mathrm{m}$ and cell length of $50-140 \mu \mathrm{m}$, which can grow in freshwater, seawater, and brackish

210 water [23]. Pediastrum is a genus of green microalgae and they are commonly growing in

211 freshwater microhabitats, such as ponds, marshes, pools, and lakes [23]. In the first 3-month

212 culture, Rhizocloniu and Pediastrum species significantly decreased to 20\%, and Desmodesmus

213 (R. Chodata) and Scenedesmus (Chlorphyceae) increased to $80 \%$ in the microalgal assemblage.

214 Desmodesmus and Scenedesmus are among the most common genera of freshwater microalgae

215 and they can grow under a wide range of environmental conditions [24]. After 5-month culture,

216 Desmodesmus dominated the microalgal assemblage with the proportion of $99 \%$. It has been

217 reported that Desmodesmus is widely distributed and has better nutrient and temperature

218 tolerance than other species [24]. In addition, Desmodesmus has small and non-flagellated cells

219 that are more shear resistant, which alleviates the cell damage caused by circulating pumps. 

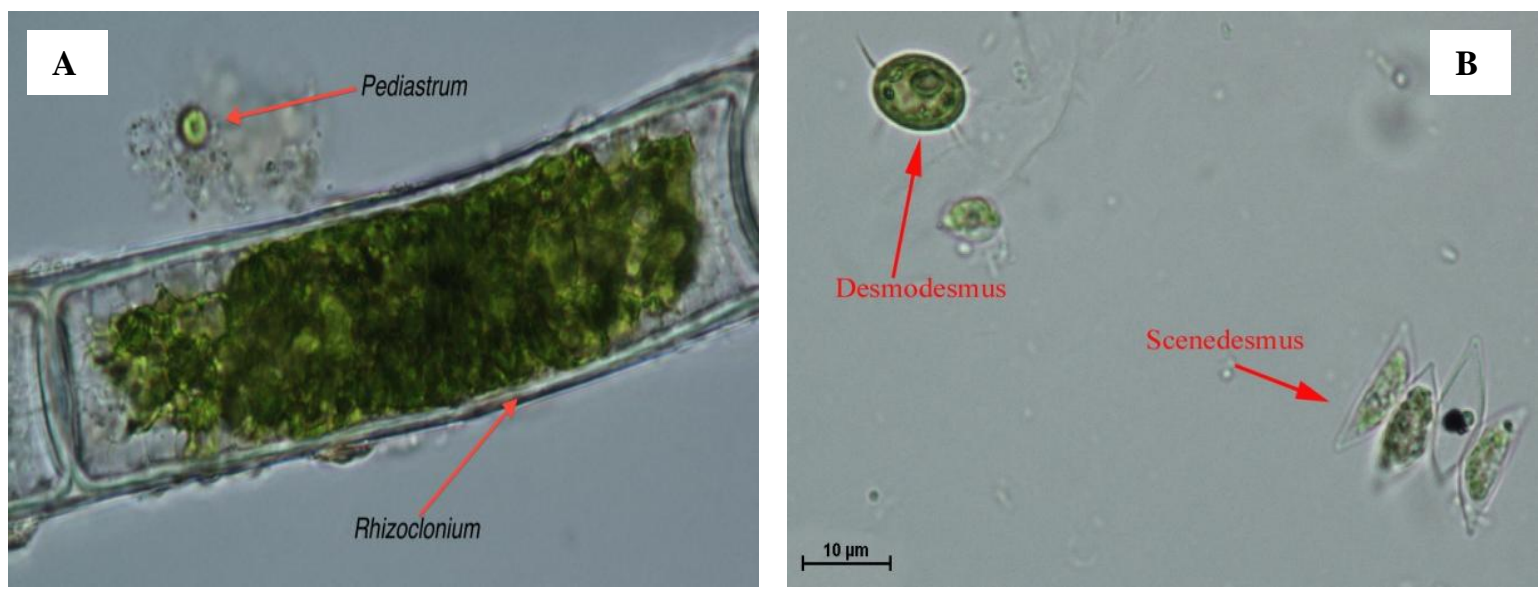

Figure 4. Microalgal assemblage selection (microscopy photo 100x). (A) Original microalgal assemblage from local freshwater pond and (B) microalgal assemblage after 3-month cultivation using wet scrubber effluents

\section{Microalgal growth performance}

The growth curve of Desmodusmus is shown in Figure 5, which demonstrated a typical sigmoid growth. Microalgae biomass was harvested around $13 \mathrm{~d}$ when the microalgal population reached its maximum density. The average growth rate was $2.2 \mathrm{~d}^{-1}$, which corresponded to the doubling time of $0.31 \mathrm{~d}$. The microalgal growth curve can be described using the following logistic growth function with MSE=0.04.

$$
y(t)=\frac{0.51}{1+3.99 \exp ^{\left(-1.68 \times 10^{6} \times t\right)}}
$$

232 Where: $\mathrm{y}(\mathrm{t})$ is the microalgal density at $\mathrm{t}(\mathrm{d})$.

The mean net biomass accumulation was $0.80 \pm 0.02 \mathrm{~g} / \mathrm{L}$ and the productivity was $12.7 \pm$

$2342.9 \mathrm{~g} / \mathrm{m}^{2} /$ day. The productivity was similar as our previous study $\left(11.2 \mathrm{~g} / \mathrm{m}^{2} /\right.$ day $)$ [9]. Raceway

235 pond bioreactors are the most common large-scale production system because they are relatively

236 economical to build and operate. However, raceway pond bioreactors have a relative low

237 productivity ranging from 0.02 to $0.2 \mathrm{~g} / \mathrm{L} /$ day [25]. Slade and Bauen [26] summarized the data 
238 from the literatures and concluded that the production of microalgal biomass in raceway pond 239 bioreactors ranged from 10.0 to $20.0 \mathrm{~g} / \mathrm{m}^{2} /$ day.

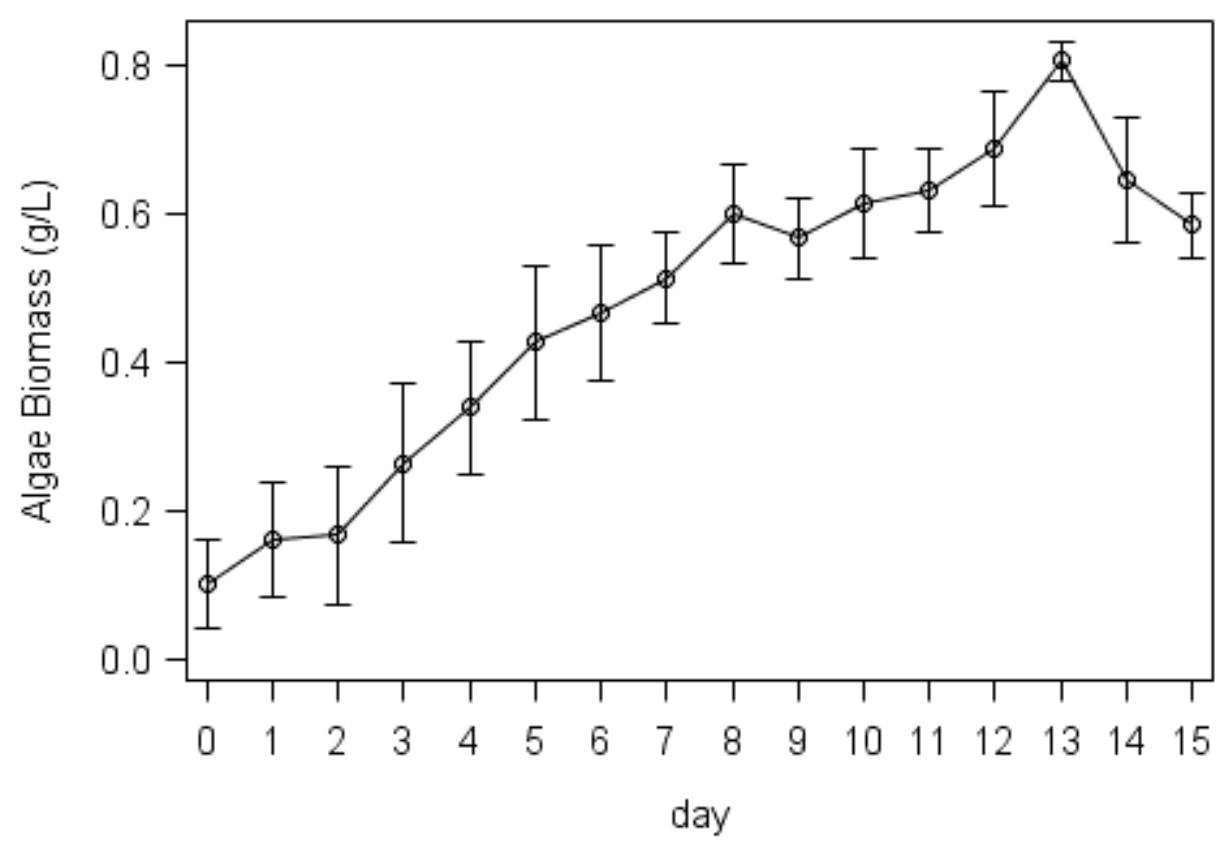

Figure 5. Microalgal growth performance.

243 Ammonia $\left(\mathbf{N H}_{3}\right)$, carbon dioxides $\left(\mathrm{CO}_{2}\right)$ and total suspended particle (TSP) mitigation

244 Concentrations of $\mathrm{NH}_{3}, \mathrm{CO}_{2}$, and TSP before and after water curtains are presented in Table

245 1. The inlet air was directly from the laying hen house, and $\mathrm{NH}_{3}$ concentrations ranged from 1.04

246 to $4.90 \mathrm{ppm}$ (Figure 6). These values were much lower than $\mathrm{NH}_{3}$ concentrations from

247 commercial facilities (20.0 ppm) [27]. Ammonia $\left(\mathrm{NH}_{3}\right)$ concentrations after the water curtain

248 (outlet $\mathrm{NH}_{3}$ concentrations) were significantly lower than inlet $\mathrm{NH}_{3}$ concentrations $(\mathrm{p}<0.05)$

249 (Figure 6). Apparently, $74.9 \%$ of the $\mathrm{NH}_{3}$ in the inlet air were removed by the water curtain

250 system. Total suspended particle (TSP) concentrations were also significantly reduced by the

251 water curtain system. The mitigation efficiencies of TSP ranged from $75.0 \%$ to $95.0 \%$. The

252 absorbed TSP could provide essential nutrients for microalgae [9]. The $\mathrm{CO}_{2}$ concentrations were 
253 not significantly reduced due to the facts of the low water solubility of $\mathrm{CO}_{2}$ (approximately $1.5 \mathrm{~g}$

$254 \mathrm{CO}_{2} / \mathrm{L}$ water) and high air flow rate from the chicken house. The $\mathrm{CO}_{2}$ concentrations in the

255 outlet of the water curtain system were around $750 \mathrm{ppm}$, which were much higher than $\mathrm{CO}_{2}$

256 concentrations in the atmosphere. Relatively high $\mathrm{CO}_{2}$ concentrations could help $\mathrm{CO}_{2}$ diffusion

257 from air into the culture media especially at alkaline $\mathrm{pH}$ condition [28], and provide carbon

258 source to enhance microalgal growth [29].

259

260

Table 1. Ammonia $\left(\mathrm{NH}_{3}\right)$, carbon dioxide $\left(\mathrm{CO}_{2}\right)$, and total suspended particles (TSP) concentrations at the inlet and outlet air of the water curtain system

\begin{tabular}{|c|c|c|c|c|c|c|c|}
\hline \multirow[t]{2}{*}{ Items } & \multirow[t]{2}{*}{$\mathrm{n}$} & \multicolumn{2}{|c|}{ Before water curtain (ppm) } & \multicolumn{2}{|c|}{ After water curtain (ppm) } & \multicolumn{2}{|c|}{ Mitigation (\%) } \\
\hline & & mean $\pm \mathrm{sd}$ & $\min , \max$ & mean \pm sd & $\min , \max$ & mean $\pm \mathrm{sd}$ & $\min , \max$ \\
\hline $\mathrm{NH}_{3}$ & 67 & $3.31 \pm 1.10$ & $1.04,4.90$ & $0.79 \pm 0.54$ & $0.04,1.94$ & $74.9 \pm 16.6$ & $28.5,98.5$ \\
\hline $\mathrm{CO}_{2}$ & 8 & $821.4 \pm 382.1$ & 604,1711 & $750 \pm 374$ & 497,1600 & $9.42 \pm 6.82$ & $0.81,18.7$ \\
\hline TSP & 9 & $27.1 \pm 10.8$ & $10.2,40.3$ & $2.91 \pm 2.18$ & $0.91,7.80$ & $89.2 \pm 6.43$ & $75.0,95.0$ \\
\hline
\end{tabular}

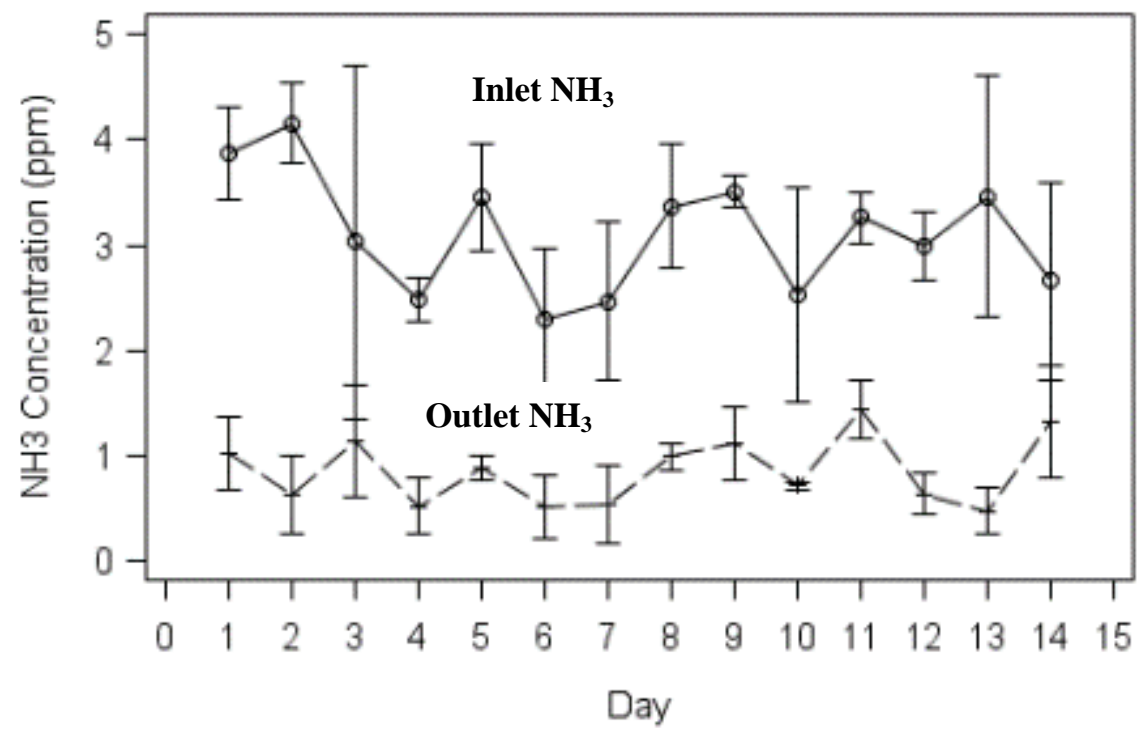
are mean values and vertical bars represent \pm standard error $(n=3)$. 
266 Changes in $\mathrm{NH}_{4}{ }^{+}, \mathrm{NO}_{3}{ }^{-}$, and $\mathrm{pH}$ of the culture media

267 Changes of $\mathrm{NH}_{4}{ }^{+}$concentrations during the culture are shown in Figure 7. The amount of

268 ammonium nitrogen $\left(\mathrm{NH}_{4}{ }^{+}-\mathrm{N}\right)$ in the culture media $\left(\mathrm{N}_{\mathrm{N} \text {-media }}\right)$ was determined by three main 269 processes (Eq. 7).

270

$$
N_{N-\text { media }}=N_{N-\text { inlet }}-N_{\text {biomass }}-N_{N-\text { outlet }}
$$

271 Where $\mathrm{N}_{\mathrm{N} \text {-inlet }}$ is the nitrogen absorbed from the inlet exhaust air (g/day), $\mathrm{N}_{\text {biomass }}$ is the nitrogen

272 assimilation by microalgae (g/day), and $\mathrm{N}_{\mathrm{N} \text {-outlet }}$ is the nitrogen loss from the culture media

273 (g/day). Transfer of ammonium nitrogen $\left(\mathrm{NH}_{4}{ }^{+}-\mathrm{N}\right)$ into the liquid phase is mainly governed by

274 the ammonia gas-liquid equilibrium $\left(\mathrm{NH}_{3}(g) \rightleftharpoons \mathrm{NH}_{3}(a q)\right)$ and the ammonium-ammonia

275 dissociation equilibrium $\left(\mathrm{NH}_{4}^{+}(a q) \leftrightharpoons \mathrm{NH}_{3}(a q)+H^{+}(a q)\right)$. Two important factors affecting

$276 \mathrm{~N}_{\mathrm{N} \text {-inlet }}$ are the droplet surface area available for $\mathrm{NH}_{3}$ mass transfer and the time available for

277 diffusion of $\mathrm{NH}_{3}$ gas molecules into the liquid droplets. In addition, some $\mathrm{NH}_{4}{ }^{+}-\mathrm{N}$ could be 278 directly released from particle-phase as well [30]. Due to the large dilution at the beginning of

279 the culture, both initial $\mathrm{NH}_{4}{ }^{+}-\mathrm{N}$ and microalgal inoculum concentrations in the culture media 280 were very low. $\mathrm{NH}_{4}{ }^{+}-\mathrm{N}$ concentrations kept increasing during the culture period because the $\mathrm{N}$

281 input $\left(\mathrm{N}_{\mathrm{N} \text {-inlet }}\right)$ was much greater than the assimilation by microalgae $\left(\mathrm{N}_{\text {biomass }}\right)$ due to low

282 inoculum concentrations. Carbon limitation might also limit the $\mathrm{N}$ assimilation by biomass. After

$28313 \mathrm{~d}$ culture, microalgae reached to the maximus biomass concentrations, the growth rate was

284 close to $0 \mathrm{~d}^{-1}$, and $\mathrm{N}$ assimilation was ceased $\left(\mathrm{N}_{\text {biomass }} \approx 0 \mathrm{~g} /\right.$ day $)$. A thermodynamic equilibrium 285 was reached and the $\mathrm{NH}_{4}{ }^{+}-\mathrm{N}$ concentrations leveled off at approximately $15 \mathrm{mg} / \mathrm{L}$ (Figure 7).

286 The $\mathrm{NO}_{3}{ }^{-}$concentrations of the culture media during batch cultures are shown in Figure 8, 287 which are similar to the trend of the $\mathrm{NH}_{4}{ }^{+}$concentrations. However, the source of $\mathrm{NO}_{3}{ }^{-}$was 
288 different from $\mathrm{NH}_{4}{ }^{+}$. The concentration of gas-phase $\mathrm{NO}_{\mathrm{x}}\left(\mathrm{NO}+\mathrm{NO}_{2}\right)$ in the exhaust air from the 289 animal facility were very low [1]. The $\mathrm{NO}_{3}{ }^{-}$was mainly from particle-phase $\mathrm{NO}_{3}{ }^{-}$in the exhaust 290 air. It was reported that particle-phase $\mathrm{NO}_{3}{ }^{-}$in $\mathrm{PM}_{2.5}$ from commercial laying hen facilities was 291 approximately $0.63 \mu \mathrm{g} / \mathrm{m}^{3}$ [30]. Since changes of $\mathrm{NO}_{3}{ }^{-}$and $\mathrm{NH}_{4}{ }^{+}$in the culture media were 292 similar, microalgae did not demonstrate their preference on nitrogen sources $\left(\mathrm{NH}_{4}{ }^{+} \mathrm{vs} \mathrm{NO}_{3}{ }^{-}\right)$, 293 which was similar to the observation of Dortch [31].

294 The $\mathrm{pH}$ of the culture media are shown in Figure 9. The $\mathrm{pH}$ was stable at approximately 9.6 295 after $4 \mathrm{~d}$ culture. The high $\mathrm{pH}$ is in favor of the formation of $\mathrm{NH}_{3} . \mathrm{NH}_{3}$ is relatively toxic to 296 microalgae and could impede microalgal growth. It has been reported that once the $\mathrm{pH}$ of culture 297 media exceeded 8.0, microalgal photosynthesis could be inhibited at $28 \mathrm{mg} / \mathrm{L}_{\text {of }} \mathrm{NH}_{3}$ in the 298 culture media [32]. Since the $\mathrm{NH}_{3}$ concentrations were relative low in our study, the inhibition of 299 high $\mathrm{pH}$ was not observed. Indeed, it has also been reported that $\mathrm{pH}$ around 9 was in favor of 300 Desmodesnus growth [33]. Good tolerance to high $\mathrm{pH}$ alleviates contamination issues caused by 301 other microbes because most of microbes co-existing with microalgae prefer acidic environment. 302 Considering that contamination is a key issue for large-scale raceway pond microalgal 303 cultivation, selecting alkaline tolerant microalgae could be a very good solution to overcome it. 


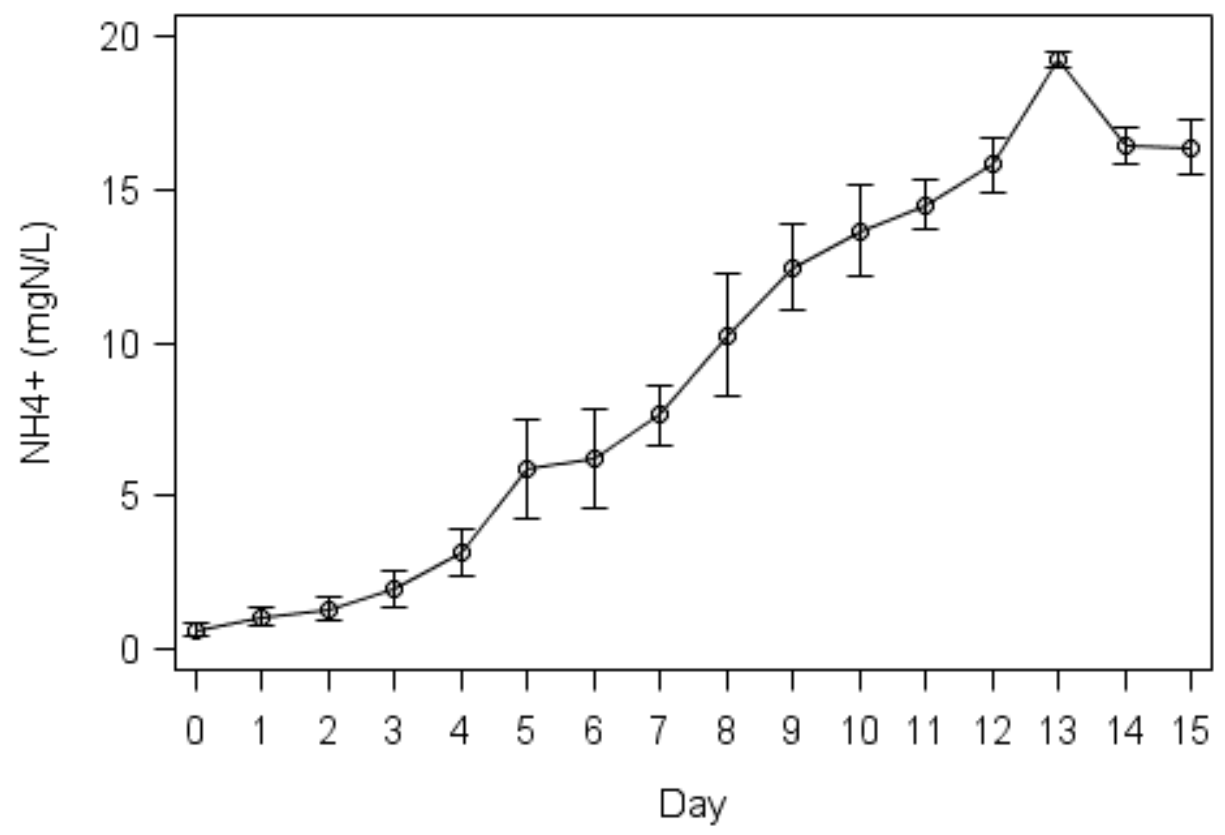

304

305

306

Figure 7. $\mathrm{NH}_{4}{ }^{+}$in the culture media during the batch culture period. Points are mean values and vertical bars represent \pm standard error $(n=3)$.

307

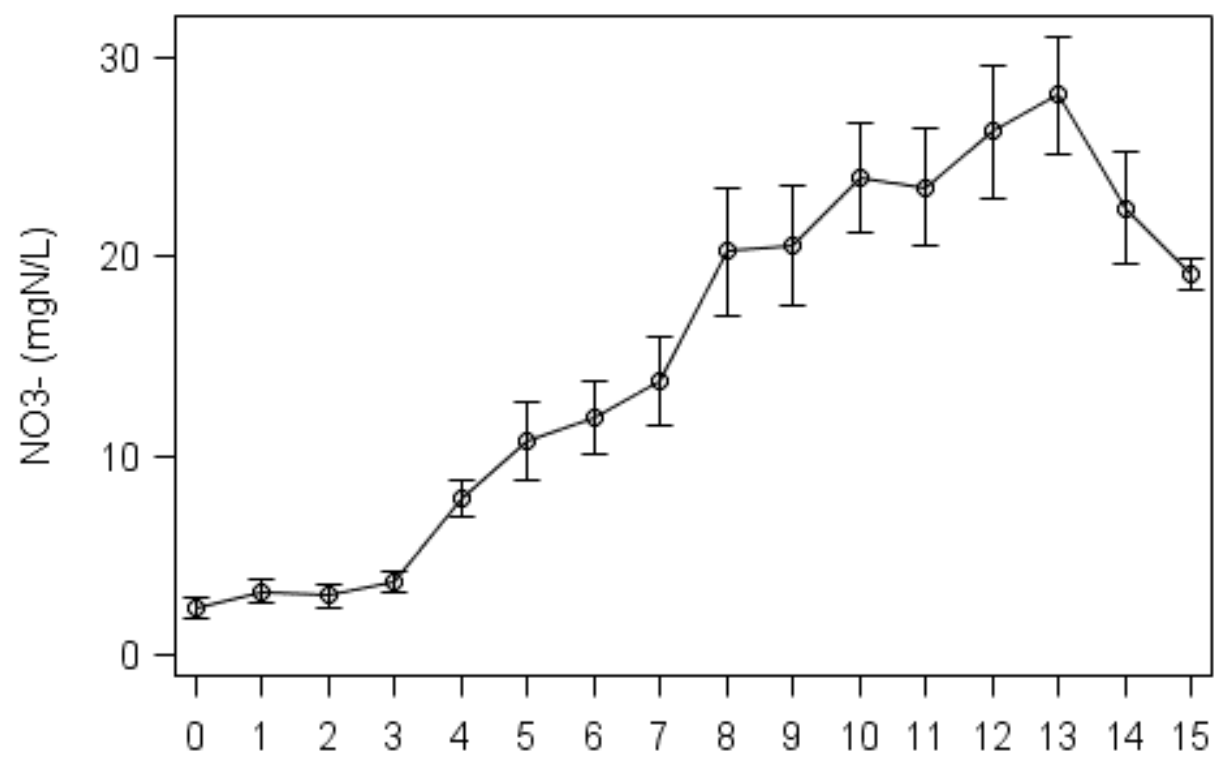

Day

309

310

Figure 8. $\mathrm{NO}_{3}{ }^{-}$in the media during the batch culture period. Points are mean values and vertical bars represent \pm standard error $(n=3)$. 


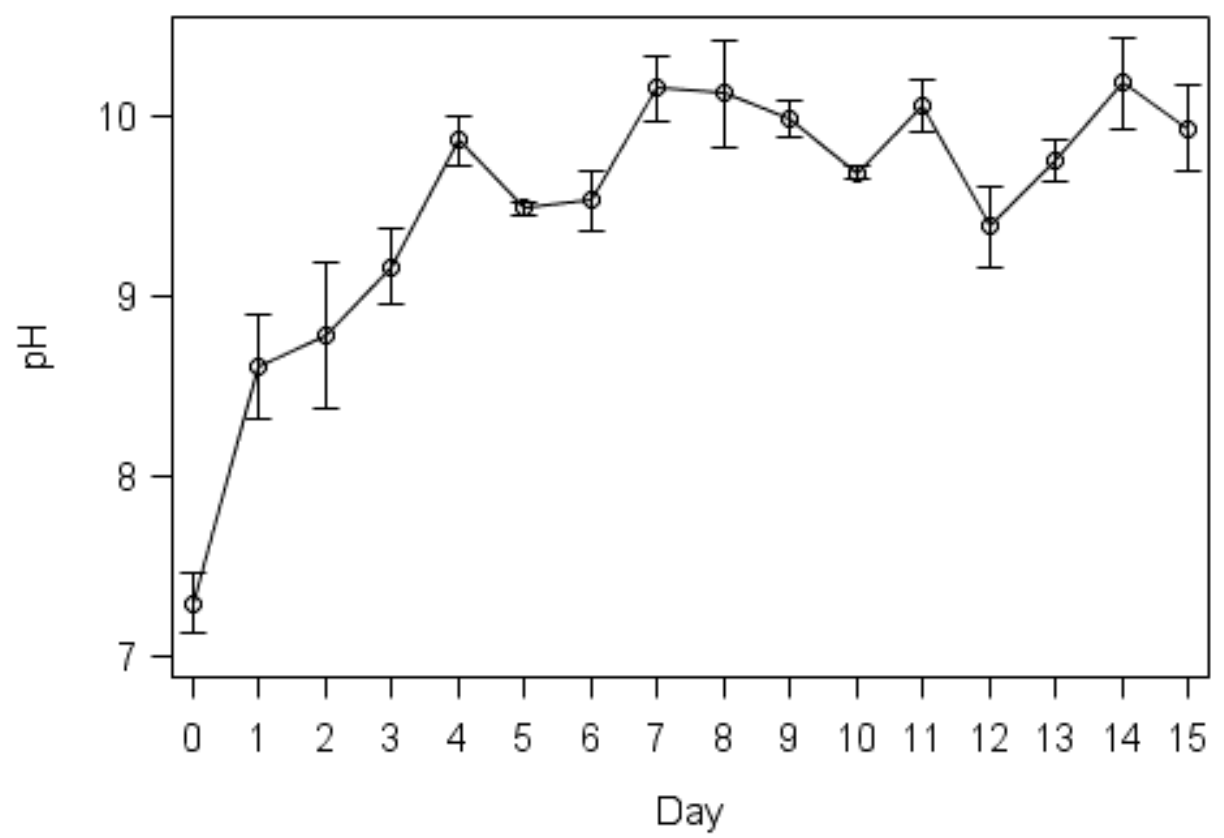

312

313

314

\section{5}

316 $325 \mathrm{~g} / 100 \mathrm{~g}$ protein, respectively. Amino acid profile varied regarding different microalgal strains. 326 For example, Boyd [34] reported lysine content of 13 species of freshwater microalgae ranged

327 from 5.23 to $8.03 \mathrm{~g} / 100 \mathrm{~g}$ protein. Becker [12] reported Aphanizomenon sp had $3.5 \mathrm{~g}$ lysine/100 $328 \mathrm{~g}$ proteins and Chlorella vulgaris had $8.4 \mathrm{~g}$ lysine/100 $\mathrm{g}$ proteins. Several nutritional and

\section{Figure 9. The culture media $\mathrm{pH}$ during the batch culture period. Points are mean values and vertical bars represent \pm standard error $(n=3)$.}

\section{Biomass analysis: protein, amino acids profile, fatty acids profile and heavy meatals concentrations}

The nutritional composition of Desmodesmus are listed in Table 2. Desmodesmus grown on the wet scrubber effluent accumulated $41.3 \%$ of crude protein and $1.91 \%$ of crude fat, and had $3,863 \mathrm{kcal} / \mathrm{kg}$ of energy content. It has been reported that under different culture conditions the crude protein of microalgae could range from $10 \%$ to $60 \%[12,20,34]$. Due to relatively high nitrogen content in the culture media, the microalgae in this study had a higher crude protein content than other reported microalgae. The amino acid profile of Desmodesmus is shown in Table 3 and they were comparable with the WHO/FAO references of egg and soybean [12]. Total essential amino acids and conditional essential amino acids were $38.5 \mathrm{~g} / 100 \mathrm{~g}$ and 22.1 
toxicological studies demonstrated that the microalgae biomass could be used as a valuable feed

330 supplement or substitute for conventional protein sources $[12,15,35,36]$. Trials in poultry feeds

331 found green microalgae Chlorella vulgaris positively affected the laying hen performance,

332 including eggs number and quality, as well as hatching performance [35]. Significantly higher

333 growth rate and lower non-specific mortality rate for turkeys were observed with Spirulina as the

334 diet supplement [37]. Swine and poultry feed trials using microalgae as the protein sources

335 resulted in higher weight gain and feed conversion efficiency [15]. In the pet food market,

336 microalgae not only promote pet health but also influence on the external appearance of the pet

337 (shiny hair, beautiful feathers) [36]. According to the crude protein content and amino acid

338 profile, Desmodesmus have comparable quality to conventional foods, therefore, they have high

339 market potential as an alternate protein source of food supplement.

$340 \quad$ Fatty acids profile of Desmodesmus is shown in Table 4. Even though the crude fat in

341 Desmodesmus biomass was only $1.91 \%(w / w)$, omega-3 fatty acids such as linolenic acid and

342 eicosapentaenoic acid (EPA) are the main components that account for approximately $23 \%$ of

343 total fatty acids. Omega-3 fatty acids have been proved as a neutraceutical supplement to prevent

344 cardiovascular disorders and cancers [38]. Omega-3 oils have a high demand in both the human

345 nutraceuticals and animal feed market [11].

346 Certain heavy metals in animal exhaust air can be potentially accumulated in microalgal

347 biomass. Several heavy metals, including arsenic, lead, copper, iron and zinc, were reported in

348 exhaust air of animal facilities [3]. The contents of these metals in the microalgal biomass were

349 listed in Table 2. NRC [39] defined the maximum tolerable level (MTL) as the dietary level that,

350 when fed for a limited period, will not impair animal performance and should not produce unsafe

351 residues in human food derived from the animal. As shown in Table 2, none of heavy metals was 
exceeded MTL [39]. However tolerance values for mineral vary with age and physiological

353 conditions of the animal, and the amount of lead and arsenic should always be maintained as far

354 below the MTL as feasible to minimize the contribution to the human diet.

355 The use of microalgal products in rations is new to many producers. Research and

356 development have been conducted on some microalgae. However, the guidelines and regulations

357 for their animal feed application have not been well developed. Factors including economics,

358 storage and handling, nutrient variation, and food safety should be considered during the

359 commercialization of such technologies.

Table 2. Nutritional composition and heavy metal concentrations of Desmodesmus biomass

\begin{tabular}{lllll}
\hline Items & W/W \% $^{\mathrm{a}}$ & Heavy metal & $\mathbf{~ m g / k g ~ ( p p m ) ~}$ & MTL $(\mathbf{p p m})^{\mathbf{c}}$ \\
\hline Dry matter & 93.7 & Arsenic $(\mathrm{As})$ & 2.4 & $50^{\mathrm{d}}$ \\
$\mathrm{CP}^{\mathrm{b}}$ & 41.3 & Lead $(\mathrm{Pb})$ & 1.1 & 30 \\
Crude fat & 1.91 & Copper $(\mathrm{Cu})$ & 54 & $250^{\mathrm{e}}$ \\
Amino Acids & 34.0 & Iron $(\mathrm{Fe})$ & 448 & $1,000^{\mathrm{f}}$ \\
ME, kcal/kg & 3863 & Zinc $(\mathrm{Zn})$ & 329 & $1,000^{\mathrm{g}}$ \\
\hline
\end{tabular}

${ }^{\mathrm{a}} \mathrm{W} / \mathrm{W} \%=$ grams per 100 grams of biomass, ${ }^{\mathrm{b}} \mathrm{CP}($ crude protein $)=6.25 \times \mathrm{N} \%,{ }^{\mathrm{c}} \mathrm{MTL}=$ maximum tolerable level, ${ }^{\mathrm{d}}$ Inorganic arsenic MTL for cattle, sheep, swine, poultry and horse, ${ }^{\mathrm{e}} \mathrm{MTL}$ for swine, ${ }^{\mathrm{f}} \mathrm{MTL}$ for cattle and poultry, ${ }^{\mathrm{g}} \mathrm{MTL}$ for swine and poultry

Table 3. Amino acid profile of Desmodesmus as compared with conventional protein sources and the WHO/FAO reference pattern ( $\mathrm{g}$ per $100 \mathrm{~g}$ protein)

\begin{tabular}{|c|c|c|c|c|c|c|}
\hline Category & Amino acids & $\begin{array}{l}\text { g per } 100 \mathrm{~g} \text { of } \\
\text { sample }\end{array}$ & $\begin{array}{l}\text { g per } 100 \mathrm{~g} \text { of } \\
\text { proteins }\end{array}$ & WHO/FAO & Egg & Soybean \\
\hline \multirow[t]{10}{*}{ Essential $^{\mathrm{a}}$} & histidine & 0.60 & 1.65 & & 2.4 & 2.6 \\
\hline & isoleucine & 1.41 & 3.88 & 4.0 & 6.6 & 5.3 \\
\hline & leucine & 3.02 & 8.32 & 7.0 & 8.8 & 7.7 \\
\hline & lysine & 2.12 & 5.84 & 5.5 & 5.3 & 6.4 \\
\hline & methionine & 0.76 & 2.09 & & 3.2 & 1.2 \\
\hline & phenylalanine & 1.84 & 5.07 & & 5.8 & 5.0 \\
\hline & threonine & 1.82 & 5.01 & & 5.0 & 4.0 \\
\hline & tryptophan & 0.27 & 0.74 & 1.0 & 1.7 & 1.4 \\
\hline & valine & 2.15 & 5.92 & 5.0 & 7.2 & 5.3 \\
\hline & sum & 14.0 & 38.5 & & & \\
\hline \multirow[t]{6}{*}{ Conditional $^{\mathrm{b}}$} & arginine & 2.62 & 7.22 & & 5.2 & 7.4 \\
\hline & cysteine & 0.47 & 1.29 & & 2.3 & 1.9 \\
\hline & glycine & 2.08 & 5.73 & & 4.2 & 4.5 \\
\hline & proline & 1.58 & 4.35 & & 4.2 & 5.3 \\
\hline & tyrosine & 1.26 & 3.47 & & 4.2 & 3.7 \\
\hline & sum & 8.0 & 22.1 & & & \\
\hline \multirow[t]{3}{*}{ Dispensable $^{c}$} & alanine & 3.01 & 8.29 & & - & 5.0 \\
\hline & aspartic Acid & 3.20 & 8.81 & & 11.0 & 1.3 \\
\hline & glutamic Acid & 4.08 & 11.2 & & 12.6 & 19.0 \\
\hline
\end{tabular}




\begin{tabular}{lllll} 
serine & 1.45 & 3.99 & 6.9 & 5.8 \\
sum & $\mathbf{1 1 . 7}$ & $\mathbf{3 2 . 3}$ & & \\
\hline
\end{tabular}

$367{ }^{\text {a }}$ An essential amino acid or indispensable amino acid is an amino acid that cannot be synthesized de novo by the 368 organism being considered, and therefore must be supplied in its diet. ${ }^{\mathrm{b}}$ Conditional essential amino acid is an amino 369 acid that its synthesis can be limited under special pathophysiological condition. ${ }^{c}$ Dispensable amino acid is an 370 amino acid that can be synthesized de novo.

\begin{tabular}{ll}
\hline Fatty acids & Percent of total fat acids \\
\hline Myristic (14:0) & 0.48 \\
C15:0 & 1.29 \\
Palmitic (16:0) & 17.8 \\
Palmitoleic (9c-16:1) & 2.00 \\
Margaric (17:0) & 0.23 \\
Stearic (18:0) & 1.22 \\
Elaidic (9t-18:1) & 0.10 \\
Oleic (9c-18:1) & 15.0 \\
Linoleic (18:2n6) & 10.1 \\
Linolenic (18:3n3) & 18.4 \\
Stearidonic (18:4n3) & 3.81 \\
Arachidic (20:0) & 0.99 \\
Gonodic (20:1n9) & 0.56 \\
EPA (20:5n3) & 0.18 \\
Behenoic (22:0) & 0.22 \\
Clupanodonic (22:5n3) & 0.21 \\
DHA (22:6n3) & 0.05 \\
Lignoceric (24:0) & 0.26 \\
\hline
\end{tabular}

\section{Conclusions}

375 Capturing and reusing nutrients in the exhaust air to culture microalgae can be a good

376 solution to achieve both emission control and value-added bioproduct generation. This study

377 developed an integrated Water Curtain-Microalgal Culture (WCMC) system to realize such

378 concept. The WCMC had $\mathrm{NH}_{3}$ and TSP mitigation efficiencies of $74.9 \%$ and $89.2 \%$,

379 respectively. The microalgal productivity was $12.7 \pm 2.9 \mathrm{~g} / \mathrm{m}^{2} /$ day. The microalgal biomass had

380 a protein content of $41.3 \%$, and the amino acid profile has a quality comparable to egg and

381 soybean. Omega-3 fatty acids accounted for about $23 \%$ of total fat acids. Heavy metals did not

382 exceed MTLs. The WCMC system is a promising technology that not only mitigates $\mathrm{NH}_{3}$ and

383 PM emissions from AFOs, but also provides a holistic solution to animal nutrient management

384 and creates a win-win situation for animal agriculture and microalgal refining. 


\section{Acknowledgment}

This project was supported by Agriculture and Food Research Initiative Competitive Grant (No. 2013-67012-21021) from the USDA National Institute of Food and Agriculture. This

project was also supported by Michigan State University (MSU) Global Center for Food Systems Innovation (Grant No. RC102194 SIG 2013-4), MSU AgBioResearch, and the Center for Global Change and Earth Observations (NASA Land Cover Land Use Change Grant to MSU -

NNX08AH50G). The authors acknowledge the generous support and collaboration of MSU

Poultry Research \& Teaching Center. Assistance from Pat Sheridan, Anh Bui, Julia Otwell, Kyle

Nussdorfer, and Hao Yao is also acknowledged.

The authors have declared no conflict of interest.

\section{References}

[1] NRC, Air Emissions from Animal Feeding Operations: Current Knowledge, Future Needs,

397 The National Academies Press, Washington, DC, 2003.

[2] X.F. Yang, X.L. Wang, Y.H. Zhang, J.M. Lee, J.W. Su, R.S. Gates, Characterization of trace elements and ions in PM10 and PM2.5 emitted from animal confinement buildings, Atmos

400 Environ, 45 (2011) 7096-7104.

401 [3] Q.F. Li, L.J. Wang-Li, R.K.M. Jayanty, S. Shah, Elemental Compositions and Chemical 402 Mass Closure of Fine Particulate in an Animal Feeding Operation Facility and Its Vicinitys, 403 Journal of Environmental Protection, 6 (2015) 409-425.

404 [4] R.B. Manuzon, L.Y. Zhao, H.M. Keener, M.J. Darr, A prototype acid spray scrubber for 405 absorbing ammonia emissions from exhaust fans of animal buildings, T Asabe, 50 (2007) 13954061407.

407 [5] L.S. Hadlocon, L.Y. Zhao, R.B. Manuzon, I.E. Elbatawi, An Acid Spray Scrubber for 408 Recovery of Ammonia Emissions from a Deep-Pit Swine Facility, T Asabe, 57 (2014) 949-960.

409 [6] S. Calvert, H. Englund, Handbook of Air Pollution Technology, Wiley, New York, 1984.

410 [7] G.M. Fu, T. Cai, Y.B. Li, Concentration of ammoniacal nitrogen in effluent from wet 411 scrubbers using reverse osmosis membrane, Biosyst Eng, 109 (2011) 235-240.

412 [8] L.J. Hadlocon, L.Y. Zhao, Production of ammonium sulfate fertilizer using acid spray wet 
scrubbers, Agric Eng Int: CIGR Journal (2015) 41-51.

414 [9] Q.F. Li, Y. Liu, W. Liao, W. Powers, Cultivating microalgae using animal production 415 exhaust air as a nutrient source, ASABE Annual International MeetingMontreal, Quebec, 416 Canada, 2014.

417 [10] A. Belay, Y. Ota, K. Miyakawa, H. Shimamatsu, Current Knowledge on Potential Health 418 Benefits of Spirulina, J Appl Phycol, 5 (1993) 235-241.

419 [11] Z. Yaakob, E. Ali, A. Zainal, M. Mohamad, M.S. Takriff, An overview: biomolecules from microalgae for animal feed and aquaculture, J Biol Res (Thessalon), 21 (2014) 6.

421 [12] E.W. Becker, Micro-algae as a source of protein, Biotechnology Advances, 25 (2007) 207422210.

423 [13] R. Abril, J. Garrett, S.G. Zeller, W.J. Sander, R.W. Mast, Safety assessment of DHA-rich 424 microalgae from Schizochytrium sp. Part V: target animal safety/toxicity study in growing 425 swine, Regulatory toxicology and pharmacology : RTP, 37 (2003) 73-82.

426 [14] A.M. Evans, D.L. Smith, J.S. Moritz, Effects of algae incorporation into broiler starter diet 427 formulations on nutrient digestibility and 3 to $21 \mathrm{~d}$ bird performance, J Appl Poultry Res, 24 428 (2015) 206-214.

429 [15] R. Ekmay, S. Gatrell, K. Lum, J. Kim, X.G. Lei, Nutritional and metabolic impacts of a 430 defatted green marine microalgal (Desmodesmus sp.) biomass in diets for weanling pigs and 431 broiler chickens, Journal of agricultural and food chemistry, 62 (2014) 9783-9791.

432 [16] L. Lardon, A. Hélias, B. Sialve, J.-P. Steyer, O. Bernard, Life-Cycle Assessment of 433 Biodiesel Production from Microalgae, Environmental Science \& Technology, 43 (2009) 64754346481.

435 [17] NAS, Sustainable Development of Algal Biofuels in the United States, The National 436 Academies Press, Washington, DC, 2012.

437 [18] A.F. Clarens, E.P. Resurreccion, M.A. White, L.M. Colosi, Environmental life cycle 438 comparison of algae to other bioenergy feedstocks, Environmental science \& technology, 44 439 (2010) 1813-1819.

440 [19] R. Chen, R. Li, L. Deitz, Y. Liu, R.J. Stevenson, W. Liao, Freshwater algal cultivation with 441 animal waste for nutrient removal and biomass production, Biomass Bioenerg, 39 (2012) 128442138.

443 [20] A.C. Wilkie, W.W. Mulbry, Recovery of dairy manure nutrients by benthic freshwater 444 algae, Bioresource Technol, 84 (2002) 81-91.

445 [21] S. Mandal, N. Mallick, Waste utilization and biodiesel production by the green microalga 446 Scenedesmus obliquus, Appl Environ Microbiol, 77 (2011) 374-377. 
450 [23] M.D. Guiry, G.M. Guiry, AlgaeBase. World-wide electronic publication, National 451 University of Ireland, Galway, 2015.

452 [24] M. Luring, Phenotypic plasticity in the green algae Desmodesmus and Scenedesmus with 453 special reference to the induction of defensive morphology, Ann. Limnol. - Int. J. Lim. , 39

454 (2003) 85-101.

455 [25] B. Ketheesan, N. Nirmalakhandan, Feasibility of microalgal cultivation in a pilot-scale 456 airlift-driven raceway reactor, Bioresour Technol, 108 (2012) 196-202.

457 [26] R. Slade, A. Bauen, Micro-algae cultivation for biofuels: Cost, energy balance, 458 environmental impacts and future prospects, Biomass Bioenerg, 53 (2013) 29-38.

459 [27] L. Wang-Li, Q.F. Li, L. Chai, E.L. Cortus, K. Wang, I. Kilic, B.W. Bogan, J.Q. Ni, A.J. 460 Heber, The National Air Emissions Monitoring Study's Southeast Layer Site: Part III. Ammonia 461 Concentrations and Emissions, T Asabe, 56 (2013) 1185-1197.

462 [28] Y.K. Lee, S.J. Pirt, $\mathrm{CO}_{2}$ Absorption Rate in an Algal Culture - Effect of pH, J Chem Tech 463 Biot B, 34 (1984) 28-32.

464 [29] E. Nielsen, Carbon dioxide as carbon source and narcoticin photosynthetic and growth in 465 Chlorella pyrenoidosa, Physiol. PI., 8 (1955) 317-335.

466 [30] Q.F. Li, L. Wang-Li, S.B. Shah, R.K. Jayanty, P. Bloomfield, Ammonia concentrations and 467 modeling of inorganic particulate matter in the vicinity of an egg production facility in 468 Southeastern USA, Environmental science and pollution research international, 21 (2014) 46754694685.

470 [31] Q. Dortch, The interaction between ammonium and nitrate uptake in phytoplankton, Marine 471 Ecology Progress Series, 61 (1990) 183-201.

472 [32] Y. Azov, J.C. Goldman, Free ammonia inhibition of algal photosynthesis in intensive 473 culturest, Applied and Enviromental Microbiology, 43 (1982) 735-739.

474 [33] L. Xia, H.J. Yang, Q.N. He, C.X. Hu, Physiological responses of freshwater oleaginous 475 microalgae Desmodesmus sp NMX451 under nitrogen deficiency and alkaline $\mathrm{pH}$-induced lipid 476 accumulation, J Appl Phycol, 27 (2015) 649-659.

477 [34] C.E. Boyd, Amino-Acid Composition of Freshwater Algae, Arch Hydrobiol, 72 (1973) 1-9.

478 [35] I. Halle, P. Janczyk, G. Freyer, W.B. Souffrant, Effect of micoralgae Chollrella vulgaris on 479 laying hen performance, Archiva Zootechnica, 12 (2009) 5-13.

480 [36] O. Pulz, W. Gross, Valuable products from biotechnology of microalgae, Applied 
481 microbiology and biotechnology, 65 (2004) 635-648.

482 [37] E.W. Becker, Microalgae in human and animal nutrition, in: A. Richmond (Ed.) Handbook 483 of Microalgal Culture, Oxford, Blackwell, 2004, pp. 312-351.

484 [38] I. Priyadarshani, B. Rath, Commercial and industrial applications of micro algae - A 485 review, J. Algal Biomass Utln, 3 (2012) 89-100.

486 [39] NRC, Mineral Tolerance of Domestic Animals, National Academy Press, Washington, DC, 4871980. 


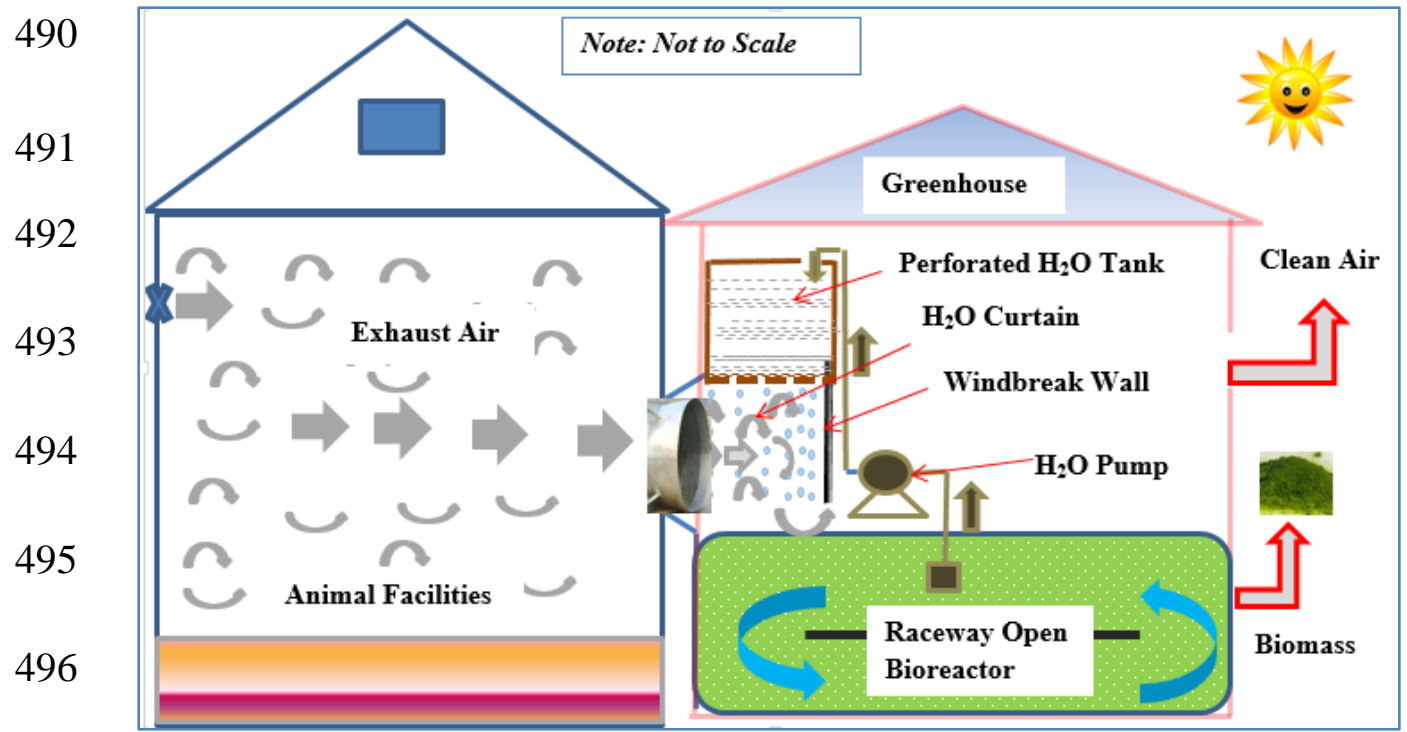

497

498 Graphical Abstract 